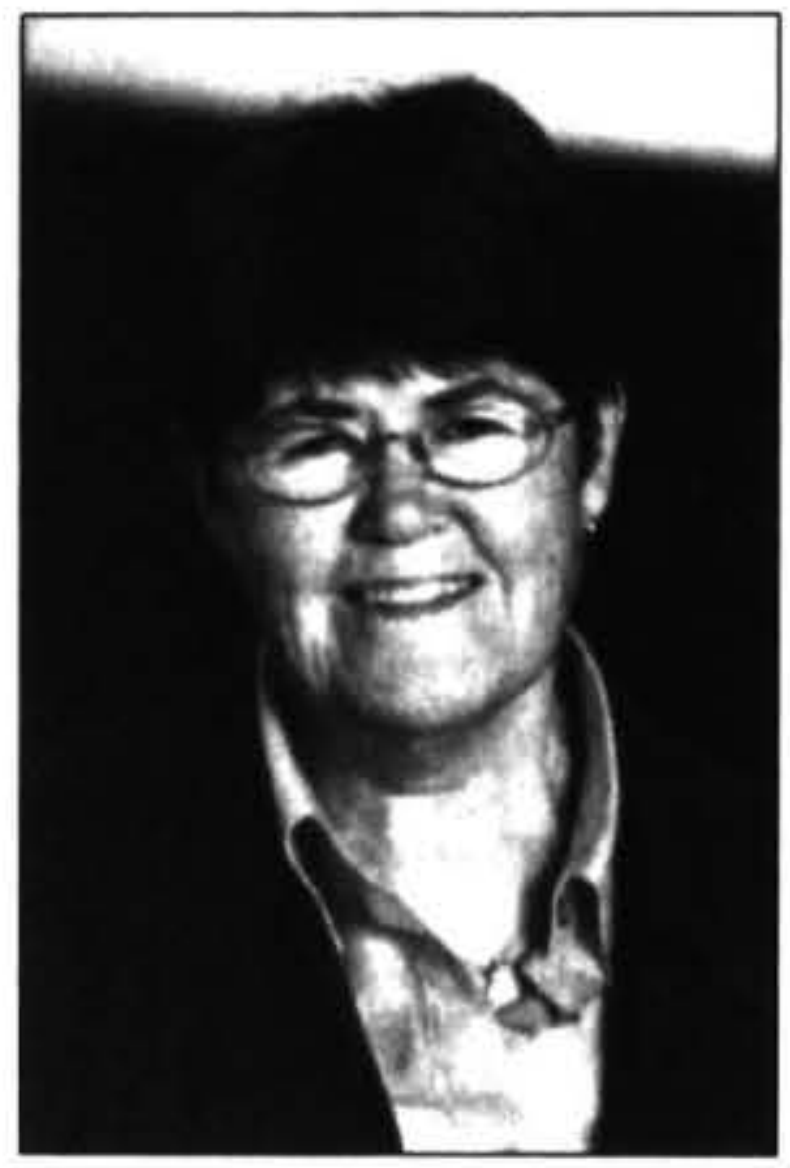

\title{
EMPLOYERS' ATTITUDES AND \\ PRACTICES ON THE HIRING \\ OF IMMIGRANTS
}

\author{
Nicola H. North \\ School of Nursing, \\ The University of Auckland
}

\begin{abstract}
A social issue to emerge in relation to skilled immigration is the severe difficulties many immigrants encounter in finding employment. A mixed method study on emplovers 'experiences, practices and policy regarding employing recent immigrants was conducted. A postal survey produced 246 questionnaires (previous/y reported). Follow-up unstructured interviews were conducted with a sub-set of 19 emplovers who wished to further discuss the matter, the focus of this paper: Results showed that in spite of overall positive experiences with immigrant emplovees, when recruiting emplovers were influenced to a large extent by previous. New Zealand work experience and to a slightly lesser extent by New Zealand qualifications. When practices of recruiting were discussed in the interviews, a complex web of reasoning on the part of emploters emerged that had the end result of severely disadrantaging immigrant applicants, particularly those from non-English speaking countries, relative to New Zealander applicants. The issues raised by emplovers that were used to the detriment of immigrant applicants included English language and communication, cultural fit, and the manner in which immigrants approached companies for emplosment. Intervien participants also commented on how immigrants could make themselves more employahle. advice that paradoxically highlighted the Catch-22 situation man! immigrant applicants find themselies in. Research is needed into the dimensions of disadvantage faced by immigrants. including the real differences and their impacts between local and immigrant applicants. Research is also needed into managers and work teams' acceptance and management of diversity in the workplace.
\end{abstract}

\section{Introduction}

Until the mid 1980s New Zealand immigration policy encouraged immigration from traditional source countries. Britain and the Pacific, delivering migrants who would both reflect New Zealand society and provide needed labour. A shift in immigration policy, parallel with other similar destination countries (e.g. Canada and Australia) reflecting global competition for skill to fuel economic growth and international competitiveness, encouraged an inflow of highly qualified and skilled young immigrants from non-traditional sources, with the expectation they would contribute to New Zealand economically and socially and settle well (see Trlin. 1986, 1992, 1997: Statistics NZ, 1999). Much has been written about the potential gains for New Zealand from increased immigration. such as: access to skills and knowledge not available in New Zealand; access to international contacts; the opening up of trade opportunities; access to investment capital: economies of scale as the population increases; and facilitation and encouragement of cultural diversity (Kerr, 1997: Ip, 1997; Mendoza. 1997: Yeabsley. 1997: and others). However, Pool and Bedford (1997), Ip (1997) and others have argued that the potential benefits of immigration are not being achieved, largely because of New Zealanders" perceptions of immigrants.
A result of negative perceptions is the severe difficulties many immigrants encounter in finding suitable employment, indeed, frequently any employment (Boyer, 1998; Department of Internal Affairs, 1996; Firkin, 2004; Ho and Lidgard, 1997; Lidgard, 1996; Pio, 2005; Trlin, Henderson and North, 1998, 2004; and others). Immigrants are unable to find jobs in the areas for which they are qualified, for reasons including qualifications (they are either overqualified or their qualifications are not recognised in New Zealand), and their lack of familiarity with the English language as spoken in New Zealand (Barnard, 1996; Department of Internal Affairs, 1996; Firkin, 2004; Lidgard, 1996; Trlin. Henderson, North, 1998, 2004; Statistics NZ 2004; see also New Zcaland Immigration Service, 2004, p.86). North and Trlin (2004) found that barriers to participating in the labour market were one reason (there were other reasons) for self-employment among immigrants. This paper shows that employers of migrants who reported overall high satisfaction with their contribution and sympathy with the plight of unemployed immigrants were nonetheless averse to employing additional immigrants.

Previous Research

Much previous research and analysis of census data has focused on the experiences of immigrants. The small amount of research from employer perspectives conducted in New Zealand highlights the disadvantage of 
immigrants - particularly non-traditional immigrants from non-English speaking countries- in the labour market, a disadvantage reflected in employment statistics. Coinciding with a rapid and large increase in skilled immigration, immigrant labour participation rates and unemployment deteriorated between the 1986 and 1996 census periods (Winkelmann and Winkelmann, 1998) and showed 16.8 per cent of recent immigrants were unemployed, compared with 7.5 per cent of New Zealand born (NZ Statistics, 1999). Unemployment rates in the 1996 and 2001 census were highest among nontraditional migrants (Statistics NZ, 2002, 2004) in spite of recent immigrants being more likely to hold a degree than New Zealand born (Statistics NZ 2004; Boyd, 2002).

Both the Department of Labour (DoL) and the commerce sector have developed initiatives to facilitate immigrant employment, including the NewKiwis scheme between Government and the Chamber of Commerce, launched in 2001, that allows for recent immigrants to get work experience (and have wages covered by Government) at no cost to businesses (see Immigration Services website). And in 2003 the Department of Labour launched an initiative, in the context of a skills shortage that could be met by immigrants, by addressing immigration and settlement processes (Wallis, 2006). However these have not been successful in overcoming employer resistance.

Discriminatory practices were highlighted in a recent classroom study involving 350 managers and professionals (MBA students) who were asked to rate 18 fictional CVs for a position; all fictional applicants were fluent in English and more than qualified for the job. The study found that mention of immigrant status and having an Indian and especially a Chinese name penalized the applicant. The researcher concluded that employers are prejudiced against ethnicity, and cover their prejudice with excuses about English and culture (reported in The New Zealand Herald 2 April 2005). Aversion to immigrants was also highlighted by the large recruitment agency Hudson. A survey of 1705 employers indicated that eight in ten believe there are barriers to immigrants participating in the workforce, and this held true across all industry sectors and regions. Employers identified non-technical skills as the most common challenge for immigrants, that is interpersonal communication and the like, but only 8 per cent thought technical skills challenged immigrants. Even in the midst of a critical skills shortage and an increasingly global market in skills continuing employer resistance to immigrants is evident (The Hudson Report 2006).

Employers who in 2003 had given a job offer to potential immigrants were surveyed. A favouring of immigrants from English-speaking countries was apparent, that is over half were to applicants from Europe, South Africa and North America (the so-called ESANA countries), while a high proportion of those without job offers were from Asian countries, in particular India. Once in the job, however, employer satisfaction with performance was very high at 88 per cent, and 93 per cent said they would hire an immigrant again (Immigration Research Services 2003). High satisfaction with immigrant employees was echoed in a 2005 study (Wallis, 2006) identifying right skills, the "right attitude", and high performance. In addition employers were positive about added values: they supplied skills not available in New Zealand, and raised organisational expertise, knowledge and innovativeness. English language difficulties, where present, did not affect job performance.

While experiences of immigrants seeking employment are well-documented and consistently point to underutilisation of immigrant skills, it is not possible to second guess the reasoning and decision-making of employers who ultimately do, or do not, accept immigrant skills. Based on a small sample of employers with positive experiences with immigrant employees, this paper reports on influences on decisions regarding future employing immigrants.

\section{Methods and Results}

There was a $40 \%$ response rate to a postal survey to employers in Wellington and Auckland (246 usable questionnaires from 611 sent out) sampled using the Top 500 Companies data base plus random sampling based on Yellow Pages. Recognising that decisions around employing immigrants is a complex issue, complexities that a postal survey is limited in understanding, respondents were invited to participate in a follow-up interview to further explore issues; 19 did so. The interviews were unstructured and participants could raise the issues important to them and that they wished to discuss. They were also asked to consider what recent immigrants, particularly skilled professionals, can do to make themselves more employable. Interviews were taped and transcribed. The paper focuses on employers' decision-making concerning the employment of immigrants, based on the interviews.

\section{Relevant Survev Results}

The survey (previously reported; see North \& Higgins 1999) showed that $70.3 \%$ did employ immigrants, with immigrants making up no more than $10 \%$ of employees for two thirds of those companies. The companies reflected a range of sizes, business activities. Immigrant employees also were diverse including skilled and less skilled, male and female and came from a wide range of countries. Survey results are not the focus of the paper. However to set a context for interview findings, relevant results are summarised. Reflecting that the many employers in The Hudson Report (2006) identified nontechnical barriers to employing immigrants, communication and social mixing were explored in the survey. Of the survey respondents, a high 89.1 percent of employers reported that English language of immigrant employees was adequate to do the job; concern about English limitations was slightly higher in the case of skilled employees, and about one third said employees were also improving their English. Only 22\% felt that English limitations posed difficulties in staff relationships; nevertheless about $89 \%$ responded that immigrant employees mixed well socially with other staff. 
Employers reported positively on the contribution of immigrant employees: $28.7 \%$ responded they worked harder or more diligently than other employees, and $48.3 \%$ at about the same level; only $1.1 \%$ said they worked less hard. This perspective was supported by numerous added comments about the benefits of employing immigrants and about their work ethic. These mainly positive comments were countered by some disappointing experiences, such as family issues taking employees overseas at short notice, using the position as a stepping stone, and expectations of higher remuneration for qualifications. Benefits to a business by employing immigrants were many. Respondents commented on the overall small labour market in New Zealand, acute and chronic occupational shortages and the need to accommodate temporary and seasonal shortages of labour. In addition, immigrant employees were widely regarded as sources of innovations, new ideas, and worldclass knowledge, and supporting the company to service an increasingly multicultural customer base, both in New Zealand and overseas. Employing people from diverse communitics was identified as a means for ensuring that the workplace reflected the community served.

In spite of those identified benefits, only 24.9 per cent of employers actively recruited immigrants to meet labour shortages: and 95.9 per cent of employers had no company policy regarding the recruitment of immigrants. Some employer respondents perceived New Zealand businesses to be generally discriminatory and suggested that such prejudice was rationalised as a concern about relationships with clients, and a misplaced emphasis on English language and company culture, issues well reflected in other studies reviewed above. For example a manager of British origin urged New Zealand companies to "give [immigrants] a go", adding that so long as there is a limited pool of skills, the employment of inmigrants will continue to be necessary. Evidence of prejudice against immigrants is seen in recruiting practices, where $71.2 \%$ and $66.8 \%$ employers respectively were influenced by New Zealand work experience and qualifications - see Table 1.

From the survey results, therefore, there appears to be some contradiction between employers' overall positive experiences and the barriers, in effect, erected by the influence on employers by applicants "New Zealand work experience and qualifications. These were issues further explored at some depth with employers. Although the interviews did not set out to look for evidence of discrimination. contradictions between overall positive employer experiences with immigrant employees and an apparent aversion to employing immigrants emerged. These contradictions are now explored in the context of employers" issues when recruiting.

\section{Interview Results}

Like survey respondents, interview participants, all of whom employed immigrants, described their experiences generally very positively (with some exceptions), and identified numerous benefits accruing to the company.
There was agreement that once in the job, such communication difficulties as existed were quickly overcome. In spite of these positive, indeed glowing, comments, when it came to recruiting employees, problems and barriers quickly assumed prominence. These potential barriers fell in three areas: communication; cultural and organisational fit; and New Zealand work experience and qualifications.

\section{Table 1: Influence of New Zealand work experience and qualifications when employing an immigrant applicant.}

$\begin{array}{llc}\text { a) Influence of New Zealand work experience } \\ & \text { Number } & \text { Per cent } \\ \begin{array}{l}\text { Strong/very strong } \\ \text { influence }\end{array} & 59 & 33.7 \% \\ \begin{array}{l}\text { Some influence } \\ \text { Little/very little }\end{array} & 68 & 38.9 \% \\ \begin{array}{l}\text { influence } \\ \text { No influence }\end{array} & 39 & 22.3 \% \\ \text { TOTALS } & 9 & 5.1 \% \\ & 175 & 100 \%\end{array}$

b) Influence of New Zealand qualifications

$\begin{array}{lll}\begin{array}{l}\text { Strong/very strong } \\ \text { influence }\end{array} & \text { Number } & \text { Per cent } \\ \begin{array}{l}\text { Some influence } \\ \text { Little/very little }\end{array} & 69 & 27.4 \% \\ \begin{array}{l}\text { influence } \\ \text { No influence }\end{array} & 48 & 39.4 \% \\ \text { TOTALS } & 10 & 27.4 \% \\ & 175 & 5.7 \% \\ & 99.9 \%\end{array}$

\section{English and Communication:}

Noting that survey results indicated that English language and communication were generally adequate to do the job, on probing the issue ability to communicate in English was repeatedly given as a reason why immigrants found it difficult to find employment. This was in spite of comments that the "technical" language was "more or less the same, I guess it doesn't matter where you come from, you can learn it".

\section{The only stumbling block is language really: It 's the only thing that makes them different from everybody else.}

Ability to communicate was said to be important both for skilled and less skilled roles, although the degree of importance increased in higher level positions. On further probing the underlying concern was not an inability to communicate but speaking in accented English. Employees with deficient English language skills were seen as a potential cost to the company: more time was needed to give instructions, the risk of error was greater, the employee gets "left behind", and the contribution of the employee lower. In addition employees commented on immigrants who tended to agree with everything and 
did not admit to not understanding. The employer then had to "double check" everything.

\begin{abstract}
[Employers expect] to give the person an instruction, a reasonable instruction, and walk away, they're not going to expect to have to spend time deciphering or making sure that the person [understands], they are going to assume that because the person's a paid professional, that he's going to understand a reasonable instruction.
\end{abstract}

Others described how English language issues could be accommodated: not putting them in roles with high customer contact or telephone answering duties: communication by computer was feasible in highly technical roles; and employees' English improved rapidly once in the job. How do employers assess adequacy of language skills when recruiting? No participant said they used formal testing, or evidence of having achieved a test. Employers relied on their personal assessment of ability to communicate:

It comes down to sitting down across the desk...And if he can actually understand. yeah ok, they've passed the test. It 's just that eve to eye contact, that voice situation.

\section{Cultural and Organisational Fit:}

Employers whose experiences with immigrant employees were generally positive, and who praised their technical skills and work ethic, nevertheless raised concerns about communication and organisational fit as reasons not to employ immigrants. The related concern for employers was: would an immigrant whose background was different fit into the company? Their concerns were multifaceted: concern for existing employees, for the immigrant employees, for working relationships vertically and horizontally, for working styles, for workplace harmony. Managerial and supervisory positions in particular were perceived as sensitive and problematic. Employers characterised New Zealand workplaces as democratic places valuing team work and worker initiative, and compared that with what they saw as "dictatorial" management styles where questioning orders was not tolerated.

Are they as a person going to fit in? That's the first thing. ...How they will relate, fit in to the staff here, not the other way round. but how in fact that they would relate to directors here and the staff. The second thing is obviously can they do the job?

Employers were anxious they didn't upset the workplace. Immigrants who were critical of New Zealand and business practices were potential risks to be guarded against. A poor fit potentially could create huge problems for the employing company, with poor integration leading to poor teamwork and lowered productivity. In the words of an employer: "You see you can't bring a guy on whose going to set everything alight and then have to recruit for all the jobs, you know?" Even a high work ethic, regarded positively in other contexts, was seen as a potential problem, threatening co-workers who are "scared for [their] job".

We have no problems in assimilating these
people to the workforce ... their work
methods are [exemplary]. [But] I guess to
some extent we ve got to be careful because
that can create a bit of resentment amongst
our own people.

When a workforce becomes ethnically diverse a management skill is to limit and manage disruptions. Managing diversity will become an increasingly important competence for managers as international migration of skills continues and workforces at company level become culturally and linguistically increasingly diverse. In the meantime, it appears that diversity even at a superficial level is not welcome in many workplaces, indeed Kiwi employees can be threatened by diversity, with immigrant applicants who look and behave differently from a Kiwi counterpart being disadvantaged.

\begin{abstract}
It's the manner. it's all the behavioural stuff. Because [when recruiting] and the majority are New Zealanders who understand New Zealand way of doing things. And then you have an immigrant who's qualified and skilled and can do the job, but have all these quirky behaviours they don't look at you in the eye, or they don't dress as well as the other applicants. all those things.
\end{abstract}

Others believed that problems of poor cultural fit were potential rather than experienced, that in fact there were few problems with fit, and immigrant employees fitted in very well, and "communication, [and] learning how things operate ... in another country", though hard, were not insurmountable. Some employers who were not put off by difference claimed prejudice was widespread.
I think particularly the Asian immigrants they do face some cultural prejudices. it's just everywhere... The Kiwi managers are not sure how to handle them because of cultural background, and ... they will trust the European first, they know how to handle them. (Interview 12)

3. New Zealand work experience and qualifications.

As for survey respondents, interview participants were influenced by New Zealand work experience and a New Zealand qualification when employing an immigrant. A number of employers described the "frightening" burdensomeness of recruiting: fears of appointing the wrong person and skills; difficulties in shedding an unsuitable employee; responsibility to appoint the best candidate; and time constraints leading to least risk decisions. Employers maintained that in the case of many companies there was "no fat in the system"; they were "lean", and therefore preferred to select an applicant who would "hit the ground running". An obvious implication of a highly competitive business environment is that where two equivalently qualified applicants were 
applying for a position, it was the one with easily verifiable qualifications and work experience and who spoke colloquial English who would get the job over an unknown applicant without local qualifications and experiences and whose English was different. Employers were reassured that immigrants were "able to work within New Zealand" when an applicant had prior local experience.

\section{I've got to put the best person in for the job ... and I've got 4 or 5 who fit with all of the appropriate skills... The reality is that it may well be that the other applicants. local knowledge. local experience makes them a better option. And ... they are going to get the job before you.}

Other reasons used by employers - and reasons were numerous - not to take on immigrants were: they were overqualified; prior experience was in too specialised a field and not generic enough for the New Zealand labour market; anxiety about "sending the wrong signals" to their own workforce; that they couldn't offer the salary they thought the applicant might expect; not wishing to be seen to exploit the immigrant (by offering a lower skilled, less paid position than warranted); upsetting workplace harmony because of being under-challenged; and fear that the immigrant might not stay, using the company as a stepping stone to a more desirable position. Immigrant job-seekers could find themselves in a Catch-22 situation, where in their endeavours to get the required experience they would apply for positions for which their qualifications were higher than needed, only to find they were rejected because they were over-qualified. Others offered to work without pay to get that experience, and this too could be rejected: employers raised objections including their risk management, not wanting 10 exploit the person, and suspecting other motivation. The following is an example of one employer:

\section{It 's had management to let him [the orer- qualified person] in the door becunse rou re going to create a prohlem for him. where he's going to be doing a menial joh. he's going to be creating for a problem fiom people working around him hecause he's going to be unhappy and you re going to have to recruit that joh again.}

Others disagreed: recruiting someone into a position low for the qualifications but in the right industry presented an opportunity to redeploy a proven and loyal employee into an appropriate position when it may arise. A few employers dismissed such comments as excuses, evidence of employer discrimination and an unwillingness to take move away from the familiar.

Emploters can use this as a reason not to c'mplos: so if the' don't really. want to take somehody on the can sal: "well really. we're looking for experience here". knowing full well, you know: it's just an excuse. And the other one lou hear is rou ire overqualified and to me that's the biggest bunch of whatever you can throw at anyone because I don't care, he may be a doctor but... if he wants to work out here as a customer services officer ... [let him].

However even sympathetic employers agreed that verifying overseas and unfamiliar qualifications and references and prior experience was more challenging in the case of an applicant with no local work record, a time consuming task that could work to the advantage of local applicants. Employers described their personal emotional difficulties in having to reject applications from desperate immigrants. Participants believed the emotional toll on employers to be a reason why many preferred to work through recruitment agencies rather than deal with applicants directly, used standard rejection letters, and did not grant appointments or give feedback.

A curious paradox has emerged. On the one hand many participants in both the survey and interviews employed immigrants, acknowledged dependence on and appreciation of their skills and work ethic, found their English language ability was adequate for the job and enjoyed the richness and interest associated with diversity. On the other hand employers displayed an aversion to the risk associated with employing immigrants and engaged in a number of strategies to avoid employing suitable applicants. This is a paradox that was more pronounced when exploring what immigrants themselves can do to convince employers to take them on.

\section{Can Immigrants Make Themselves More Employable?}

Employers were invited to comment on what advice they would give to immigrant job-seekers. Here too, as for other issues such as communication, cultural fit, and a preference for New Zealand work experience and qualifications, there were employers who disagreed with the majority view, seeing it as evidence of prejudice. Some advice was very pragmatic, that immigrants simply need to demonstrate to the prospective employer that all permits and documentation was in order, that diplomas in other languages had verified copies in English, NZQA assessed qualifications and the like. Other advice flowed on from the above concerns regarding English communication - that "their language skills are bang on" and cultural fit:

\section{The most important. they ve got to be presentable, they ve got to be clean. they've got to have an understanding of courtesy.}

A problem for recently arrived immigrants, however, is to get the exposure to New Zealand society in order to come to an understanding of the subtleties of colloquial English and cultural mores and mannerisms, an exposure that participation in employment provides. There is also the problem that "bang-on" English language skills are of no help to immigrants who cannot reach the interview stage, often because their name gives away their "foreign" background. Some employers described as "tricks" initiatives used by immigrants to increase their chances of getting to interview stage such as using a friend with 
adequate English to make a phone-call and adopting an English name. Employers favoured applications that demonstrated the applicant had "done their homework", for example had information about the company and position, a targeted $\mathrm{CV}$, had the expected qualifications for the position and so on. For example:

Well you have to sort of prove that your qualifications are... we have to sort of match what they mean in New Zealand ... try and show the learnings of your experience to the Kiwi experience....

So it's to show whatever experience you've got from whatever country you come from. how similar and how relative it is to the Kiwi one...

For an immigrant applicant to be able to demonstrate equivalence, however, it is necessary to first gain an understanding of the New Zealand employment context in their field. Employers also displayed contradictory positions on immigrants who did, and did not, pursue employment opportunities. Many made clear their reluctance to open up the workplace to "cold callers" and unsolicited applications, dismissing rejected applicants who seek to find out why as "pushy".

They're persistent. They arrived in, ring you up, first to check that you ve got their. $C V$, yes we have, and what are you doing about it, well we'll see how many. applicants we get, we 're still waiting on the closing date, expect a call from us.

Others advised that immigrant job seekers do exactly this.

Don't just look in the newspapers, go and actually sell yourself to companies, knock on doors.

A final area of advice concerned flexibility on the part of the immigrant job-seeker. Some suggested immigrants worked voluntarily to gain required local experience, but in other contexts discouraged unpaid work as a risk to the company. Furthermore, although employers had highlighted the problems they encountered of "overqualified" immigrant applicants, they also advised immigrants to be prepared to settle for something less than their qualifications and work experience deserved:

You can't be fussy if you're looking at establishing a new life in a country: ...taking the first opportunity and getting the Kiwi experience.... be prepared to come in perhaps at the lower level. prepared to start at a more junior position and climb the ladder...

If all the above failed, as often it did, employers suggested that immigrants could up-skill, get another qualification, in spite of the risk to the immigrant job seeker of becoming even less employable as an overqualified immigrant. The onus, then, was on the immigrant job-seekers to demonstrate their suitability for a position and if not, to take steps to make themselves more employable. However as we have also seen, even these measure were no guarantee of success, especially in a context of employers being averse to immigrants in general, and in some cases prejudiced against employing immigrants from particular backgrounds.

\section{Conclusions}

The paper highlighted a paradox that has been reflected in other studies and the media. Emigration of New Zealand talent combined with demographic ageing has led to serious and growing shortages in skills necessary for economic growth. Employers say they need skilled people and complain of shortages. Immigration policy over the last two decades has sought to address the need for skills by targeting young, skilled migrants, but employers systematically discriminate against immigrant job seekers, especially those from non-English speaking countries. Although employers claimed they were seeking to recruit the best skills possible, in practice it appeared that skills obtained through qualifying and working in New Zealand outweighed other considerations. The better skilled immigrant might then be rejected for being overqualified for the position, for not speaking colloquial English, and because of fears the person would not "fit".

Interview participants outlined the employer's perspective on the disadvantages and barriers immigrants faced when seeking employment, and in their descriptions indicated that in practice one disadvantage compounded the next. culminating in barriers to immigrant job seekers becoming almost insurmountable.

In light of the very high levels of satisfaction with immigrant employees, the finding that English was normally adequate for the job, and that immigrants delivered a range of benefits to the company in addition to their labour and skills, an unavoidable conclusion is that immigrants face prejudice in the labour market. Other research and employers themselves have come to the same conclusion: for example The Hudson Report (2006) found a high 77 per cent of employers believed there were barriers to immigrants.

A number of commentators agree that employers need to change (e.g. Ho, Cheung, Bedford \& Leung, 2000; The Hudson Report, 2006). Specifically employers need to recognise: the value of experience gained overseas; the value of languages other than English; the cultural capital immigrant employees offer; and diversity as an asset. To this end there have been a very limited number of resources prepared that employers can use to support an attitudinal shift. One example is the EEO Trust (2000, 2005) that has developed a set of resources to assist employers in developing policies and practices that will support diversity in the workplace. Another is the Auckland Chamber of Commerce (2001-5) initiative that allows employers to trial immigrants at no cost to the company. Workplaces and work groups would benefit from diversity. Immigrant employees offer tangible assets including language skills and cultural capital, networks 
with ethnic communities and with businesses in countries of previous employment, and less tangible assets including high work ethic and performance, commitment and loyalty.

\section{Future Research}

Research is needed into the labour market, employers and workplaces, to determine the extent, nature and dimensions of what appears to be systematic disadvantages faced by immigrants in the labour market. Research is also needed to identify organisational practices that effectively reduce those barriers, policies that support diversity in relation to both recruitment and retention of employees, and programmes to support and integrate (not assimilate) immigrant employees and the assets they bring into the workplace.

It is possible employment difficulties of qualified immigrants reflects a more complex set of issues than can be explained by prejudice alone, and human capital theory could guide future research into whether there are real differences between immigrant and native born employees. Concerns expressed by participants that could be researched more thoroughly include comparability between New Zealand and overseas qualifications, the impact of unfamiliarity with local business knowledge, the size of discrete labour markets for the professions and qualifications immigrants represent, the differences in the degree of specialization in those labour market between New Zealand and large overseas labour markets, language proficiency and communication, and cultural knowledge.

\section{References}

Auckland Chamber of Commerce (2001-2005). New Kiwis - An Emplorment Site where the Focus is on Skills. http://www.newkiwis.co.nz/aboutus.asp Retrieved 5/09/2006.

Barnard, R. (1996). What Issues do Recent Immigrants Face in New Zealand? A Qualitative Study of Three Professional Groups: Health Professionals, Engineers and Teachers. Wellington: Victoria University of Wellington.

Boyd, C (2002). Migrants in New Zealand: An Analysis of Lahour Market Outcomes for Working Aged Migrants Using 1996 and 200/ Census Sata. Wellington: Department of Labour.

Boyer, T.M. (1998). Is immigration really working? The employment status of the Taiwanese community in Auckland. In Proceedings of the $18^{\text {th }}$ Conference. New Zealand Geographical Societn: University of Canterhury: 27-30 August, 1995. 208-211.

Department of Internal Affairs (1996). High hopes: A Surver of Qualifications. Training and Employment Issues for Recent Immigrants in New
Zealand. Wellington: Department of Internal Affairs.

EEO Trust (2000). Making the Most of a Diverse Workforce: An Employer's Guide to EEO. Auckland: Equal Employment Opportunities Trust

EEO Trust (2005). Versatile Workforce, Business Success: Maximize your Business Potential with a Diverse Workforce. Auckland: Equal Employment Opportunities Trust

Firkin, P. (2004). 'New Zealand Experiences': Biographical Narratives of Professional Migrants on Working in New Zealand. Labour Market Dynamics Research Programme Research Report Series 2004/2. Auckland: Massey University.

Ho, E. and Lidgard, J.M. (1997). Give us a chance: The employment experiences of new settlers from East Asia. In Morrison, P.S. (ed) Labour, Employment and Work in New Zealand. Proceedings of the $7^{\text {th }}$ Conference, 28-29 November, 1996. Wellington: Institute of Geography, Victoria University of Wellington.

Ho, E., Cheung, E., Bedford, C. and Leung, P. (2000). Settlement Assistance Needs of Recent Migrants. Wellington: New Zealand Immigration service.

Immigration Research Programme (2003). Skilled Migrants: Labour Market Experiences. Wellington: Department of Labour.

Ip, M. (1997). Successful settlement of migrants and relevant factors for setting immigration targets. In The Population Conference - People. Communities, Growth. Conference Proceedings, Wellington. 12-14 November, 1997. Online www.executive.govt.nz/minister.bradford/populati on/index

Kerr, R. (1997). Immigration and the labour market. In The Population Conference - People, Communities, Growth. Conference Proceedings, Wellington, 12-14 November, 1997. Online. www.executive.govt.nz/minister.bradford/populati on/index

Lidgard, J.M. (1996). East Asian migration to Aotearoa/New Zealand: Perspectives of some new arrivals. Population Studies Centre Discussion Paper Number 12. Hamilton: Department of Geography, University of Waikato.

Mendoza, S. (1997). Population change and the business sector. In The Population Conference - People, Communities. Growth. Conference Proceedings, Wellington. 12-14 November. 1997. Online www.executive.govt.nz/minister.bradford/populati on/index

New Zealand Immigration Service (2004). Migrants' Experiences of New Zealand. Wellington: New Zealand Immigration Service. 
North, N. and Higgins, J. (1999). The employment of immigrants in New Zealand: employers' perspectives and experiences. In Tipples, R. and Shrewsbury, H. (eds) (1999). Global Trends and Local Issues. Proceedings of the Seventh Annual Conference of the International Employment Relations Association, Lincoln University 13-16 July 1999, pp 423-435.

North, N. and Trlin, A. (2004). Immigrants in Business: A Study of Self-Employed Immigrants and Their Business in New Zealand. New Settlers Programme Occasional Publication Series No. 10. Palmerston North: Massey University.

Pio, E. (2005). Standing in the foyer: Work experiences of Indian women migrants in New Zealand. Equal Opportunities International. 24(1), pp58-76.

Pool, I. and Bedford, R. (1997). Population change and the role of immigration. In The Population Conference - People, Communities, Growth. Conference Proceedings, Wellington, 12-14 November, 1997. Online: www.executive.govt.nz/minister.bradford/populati on/index

Statistics New Zealand (1999), People Born Overseas. Wellington: Statistics New Zealand.

Statistics New Zealand (2002). 2001 Census of Population and Dwellings: People Born Overseas. Wellington: Statistics New Zealand.

Statistics New Zealand (2004). Degrees of Difference: The Employment of University-Qualified Immigrants in New Zealand. Wellington: Statistics New Zealand

The New Zealand Herald (2005). Foreign workers face battle to win jobs. 2 April, 2005.

The Hudson Report (2006). Employment and HR trends New Zealand July-December 2006 Part 2. HR Insights. New Zealand: Hudson

The Office of Ethnic Affairs (2002). Ethnic Perspectives in Policy. Wellington: Department of Internal Affairs.

Trlin, A. (1986). New Zealand's immigration policy in the early 1980s. In Trlin, A.D. and Spoonley, P. (1986) New Zealand and International Migration: a digest and bibliography, Number 1. Department of Sociology, Massey University.
Trlin, A. (1992). Change and continuity: New Zealand's immigration policy in the late 1980s. In Trlin, A.D. and Spoonley, P. (1992). New Zealand and International Migration: A Digest and Bibliography, Number 2. Department of Sociology, Massey University.

Trlin, A. (1997). For the promotion of economic growth: New Zealand's immigration policy, 1991-1995. In Trlin, A.D. and Spoonley, P. (1997). New Zealand and International Migration: A Digest and Bibliography. Number 3. Department of Sociology, Massey University.

Trlin, A., Henderson, A., North, N. (1999). Effects of unemployment among skilled immigrants from India. New Zealand Population Review, 25, 1-19.

Trlin, A., Henderson, A. and North, N. (2004). Skilled Chinese and Indian immigrant workers. In Spoonley, P., Dupuis, A. and De Bruin, A. (eds) (2004). Work and Working in Twenty-First Century New Zealand. Palmerston North: Dunmore Press.

Wallis, R. and BRC Marketing and Social Research Ltd. (2006). Skilled Migrants in New Zealand: Employers' Perspectives. Wellington: Department of Labour.

Winklemann, L. and Winkelmann, R. (1998). Immigrants in New Zealand: A Study of Labour Market Outcomes. Labour Market Policy Group Occasional Paper 1998/1. Wellington: Department of Labour.

Yeabsley, J. (1997) Successful settlement of migrants and relevant factors for setting immigration targets. In The Population Conference - People, Communities, Growth. Conference Proceedings. Wellington. 12-14 November, 1997. Online. www.executive.govt.nz/minister.bradford/populati on/index

\author{
Author \\ Nicola H. North \\ Associate Professor \\ School of Nursing \\ The University of Auckland \\ Private Bag 92019 \\ Auckland Mail Centre \\ Auckland 1142 \\ N.North@auckland.ac.nz
}

